\title{
Release and distribution changes of phosphorus in three alkaline sandy soils as a function of bone char applications
}

\author{
Abu El-Eyuoon Abu Zied Amin ${ }^{1}$ \\ ${ }^{1}$ Assiut University Faculty of Agriculture
}

October 17, 2021

\begin{abstract}
An incubation experiment was carried out to assess bone char application on the availability and distribution of phosphorus in agricultural alkaline sandy soils. Three alkaline agricultural sandy soils in Upper Egypt have been collected from Arab El-Awamer at Assiut governorate, West El-Minia at El-Minia governorate, and New Valley Governorate. 100 grams were taken from each soil under study and placed in a plastic jar. The bone char is applied at level $0.4 \mathrm{~g}$ jar- 1 into these soils. This experiment was incubated at $23{ }^{\circ} \mathrm{C}$ in the dark for periods of $7,16,35,65$, and 84 days and arranged in a completely randomized design with three replicates. The results revealed that bone char applications to the soils resulted in a significant positive increase in the availability of phosphorus affected by the soil type and incubation periods in Arab El-Awamer soil. The percentage of increase in available phosphorous after adding bone char compared to before incubation was as follows: Arab El-Awamer soil ¿New Valley soil ¿West El-Minia soil. The available phosphorous was negatively correlated with electrical conductivity ( $\mathrm{r}=-$ $\left.0.288^{*}\right)$, soluble calcium $\left(\mathrm{r}=-0.306^{*}\right)$, and soluble sulfate $\left(\mathrm{r}=-0.413^{*}\right)$. The concentrations of NH4Cl-Pi, NaHCO3-Pi, NaOH-Pi, $\mathrm{HCl}-\mathrm{Pi}$, residual-P fractions increased significantly in some soil types with applying bone char. The concentrations of available phosphorous in all soils under study were positively correlated with all phosphorus fractions. We conclude that bone char applications into P-poor soil are important to potentially enhance phosphorus availability. Bone char is considered a promising strategy in sustainable agriculture.
\end{abstract}

Release and distribution changes of phosphorus in three alkaline sandy soils as a function of bone char applications

Abu El-Eyuoon Abu Zied Amin ${ }^{a^{*}}$

${ }^{a}$ Soils and Water Department, Faculty of Agriculture, Assiut University, Assiut, Egypt, P.O. Box: 71526, tel: 00201143784083

*Corresponding Author: Abu El-Eyuoon Abu Zied Amin [abueleyuoon.amin@aun.edu.eg (A. A. Amin)]

Running Title: changes of phosphorus release in alkaline sandy soils

\section{Abstract}

An incubation experiment was carried out to assess bone char application on the availability and distribution of phosphorus in agricultural alkaline sandy soils. Three alkaline agricultural sandy soils in Upper Egypt have been collected from Arab El-Awamer at Assiut governorate, West El-Minia at El-Minia governorate, and New Valley Governorate. 100 grams were taken from each soil under study and placed in a plastic jar. The bone char is applied at level $0.4 \mathrm{~g} \mathrm{jar}^{-1}$ into these soils. This experiment was incubated at 23 ${ }^{\mathrm{o}} \mathrm{C}$ in the dark for periods of $7,16,35,65$, and 84 days and arranged in a completely randomized design with three replicates. The results revealed that bone char applications to the soils resulted in a significant positive increase in the availability of phosphorus affected by the soil type and incubation periods in Arab 
El-Awamer soil. The percentage of increase in available phosphorous after adding bone char compared to before incubation was as follows: Arab El-Awamer soil ¿New Valley soil ¿West El-Minia soil. The available phosphorous was negatively correlated with electrical conductivity $\left(\mathrm{r}=-0.288^{*}\right)$, soluble calcium $\left(\mathrm{r}=-0.306^{*}\right)$, and soluble sulfate $\left(\mathrm{r}=-0.413^{*}\right)$. The concentrations of $\mathrm{NH}_{4} \mathrm{Cl}-\mathrm{Pi}, \mathrm{NaHCO}_{3}-\mathrm{Pi}, \mathrm{NaOH}-\mathrm{Pi}, \mathrm{HCl}-\mathrm{Pi}$, residual-P fractions increased significantly in some soil types with applying bone char. The concentrations of available phosphorous in all soils under study were positively correlated with all phosphorus fractions. We conclude that bone char applications into P-poor soil are important to potentially enhance phosphorus availability. Bone char is considered a promising strategy in sustainable agriculture.

\section{Highlights}

1. Properties of alkaline soils may affect the availability and fractions of phosphorous with the application of bone char

2. The use of bone char as a safe, clean, and cheap alternative to synthetic phosphate fertilizers

3. Soluble calcium and electrical conductivity were factors that most affected the release of phosphorus from bone char in different alkaline soils

4. The bone char applications to P-poor soil are important to improve phosphorus availability.

5 . Bone char represents a promising strategy in sustainable agriculture

Keywords: Alkaline soils; Available phosphorus; Bone char; Phosphorus fractions; Soluble calcium

\section{Introduction}

Phosphorous in plants is one of the nutrients that play an important role in the fertilization of agricultural soils, as large quantities of it are added to the soil (Hopkins \& Ellsworth, 2005). Recently, finding renewable resources as substitutions of chemical phosphate fertilizer to face the steadily increasing global demand for food, become an important issue because the traditional recourses of chemical phosphate fertilizer such as rock phosphate, which is considered the main source of phosphorus, are non-renewable and expected to deplete rapidly during 50-100 years this is attributed to the increased demand of phosphate fertilizers (Cordell et al., 2009). Excessive application of phosphate chemical fertilizers as a result of the increasing demand for food has led to increased pollution with heavy and radioactive elements in the soil and the environment, which is a cause of the deterioration of the ecosystem (Attallah et al., 2019: Khan et al., 2018).

Generally, natural resources must be managed sustainably while minimizing the use of non-renewable energy sources. These measures must be of economic, environmental, and social return (Sarkar et al., 2020). Recycling slaughterhouse waste, especially bone, and converting it into bone char, is one of the processes used to preserve soil fertility, especially phosphorus. Bone char is considered to be a clean and renewable alternative to chemical phosphate fertilizers as well as help protect society and the environment via disposing of waste in a safe manner (Glæsner et al., 2019; Amin, 2020). Bone char was a highly efficient phosphate fertilizer from dried bones, possibly attributable to mineralogical changes during the pyrolysis process (Glæsner et al., 2019). Furthermore, bone char contains negligible amounts of heavy metals as well as it is free of radionuclides and organic contaminants such as pharmaceuticals (Siebers \& Leinweber, 2013; Zimmer et al., 2019). The bone contains apatite classified as biogenic crystalline apatite which can be differentiated from geological apatite- exists in rock phosphates- by its small crystal size, high carbonate substitution, substantial $\mathrm{OH}$ deficiency, vacancies in the lattice, and the resultant increased solubility. All these factors cause high solubility of the biological apatite (Wopenka \& Pasteris, 2005; Boskey, 2007). Several studies observed that the amount of available phosphorus in soils with bone char application was higher than the phosphate rock (Warren et al., 2009; Vassilev et al., 2013). Phosphorus release from bone char into the soil is affected greatly by the chemical properties of the soil (Warren et al., 2009; Amin, 2021).

Phosphorus status in the soil is strongly affected by many important mechanisms is releasing, leaching, sorption, desorption, mineralization, immobilization, and precipitation (Zhu et al., 2018). It is worth noting that the phosphorous availability in alkaline soil is highly influenced by several factors such as soil texture ( Pizzeghello et al., 2011; Jalali \& Jalali, 2016), calcium carbonate content (Leytem \& Mikkelsen, 2005), soil salinity (Bai et al., 2017), soil pH, soluble cations (sodium, calcium, and magnesium), soluble anions 
(chloride, nitrate, and sulfate), and total phosphorus (Li et al., 2019). One of the hypotheses of this study was the significant effect of the chemical properties of the soils on the release of phosphorus from bone char. Most previous studies of bone char were performed in acid soils. However, the current study presents important insights on the application of bone char on the availability and distribution of phosphorus in three agricultural alkaline sandy soils.

\section{Materials and Methods}

\section{Soil Collection and Analyses}

Three alkaline agricultural soils in Upper Egypt which are widely differing in chemical properties were collected from the surface layer $(0-20 \mathrm{~cm})$ of Arab El-Awamer at Assiut governorate, West El-Minia at El-Minia governorate, and New Valley Governorate. Soil samples were air-dried, ground to pass through a 2-mm sieve, and kept for incubation experiment. These soils are classified as Entisols: Typic Torripsamments (U.S. Soil Taxonomy). Physico-chemical properties of the soils under study were presented in Table 1 . The bone char used in this experiment was produced at 650 0C for 2 hours. Some chemical characteristics of the bone char are given in Table 2 cited from Amin (2020). One hundred grams were taken from the soils under study and put in an airtight plastic jar $(330 \mathrm{ml})$. Added 0.4 gram of bone char to all the soils in the jars and mixed thoroughly. All treatments were moistened until the field capacity by distilled water, arranged in a completely randomized design with three replicates, and incubated at $23{ }^{\circ} \mathrm{C}$ in the dark for periods of $7,16,35,65$, and 84 days. The jars opened now and then to maintain the aerobic conditions and moisture content of the soil at field capacity by weighing the jars by adding distilled water equivalent to the loss of the water. At the end of each incubation period, soil samples were taken, air-dried, and crushed to be used for chemical analysis.

\section{Soil chemical analysis}

The soil $\mathrm{pH}$ was measured in distilled water suspension (1:1) via a glass electrode. Electrical conductivity (EC) was measured in the soil extracts 1:2.5 (soil to water ratio) using an electrical conductivity meter. Soluble $\mathrm{Ca}$ and $\mathrm{Mg}$ in the soil extracts were determined by titration using $\mathrm{Na}_{2}$ EDTA solution (disodium ethylene diamine tetra-acetic acid); soluble Na was measured by flame photometry method. Soluble bicarbonate $\left(\mathrm{HCO}_{3}\right)+$ carbonate $\left(\mathrm{CO}_{3}\right)$ was titrimetrically determined using $\mathrm{HCl}$ acid, soluble sulfate was estimated by the turbidimetry method using barium chloride (Baruah \& Barthakur, 1997), and soluble chloride was determined using silver nitrate solution (Jackson, 1973). The available phosphorus (Olsen-P) in soil samples was extracted by $0.5 \mathrm{M} \mathrm{NaHCO}_{3}$ at $\mathrm{pH} 8.5$ according to Olsen et al. (1954). Sequential fractionation of inorganic phosphorus in soil samples has followed the procedure described by Hedley et al. (1982) and modified by Chen et al. (2000). 2.50 grams of the soils were placed in a centrifuge tube $100 \mathrm{~mL}$ for the sequential fractionation. The $\mathrm{P}$ fractions were extracted in sequence were: Soil sample in any tube extracted with $50 \mathrm{ml}$ of $1 \mathrm{M} \mathrm{NH}_{4} \mathrm{Cl}, 0.5 \mathrm{M} \mathrm{NaHCO}_{3}$ at $\mathrm{pH}$ 8.5, The extract included inorganic $\mathrm{P}\left(\mathrm{NaHCO}_{3}-\mathrm{Pi}\right), 0.1 \mathrm{M}$ $\mathrm{NaOH}$, this extract to determine the $\mathrm{NaOH}-\mathrm{Pi}, 1 \mathrm{M} \mathrm{HCl}$ this extract to determine the $\mathrm{HCl}-\mathrm{Pi}$, each of the four previous fractions were shaken for $16 \mathrm{hrs}$ and then centrifuged for $7 \mathrm{~min}$ (4000 rpm). The soil residue from the last fraction was digested with concentrated $\mathrm{H}_{2} \mathrm{SO}_{4}, \mathrm{HNO}_{3}$, and $\mathrm{HClO}_{4}$, this extract represents the residual $\mathrm{P}$. Phosphorus in the extracts was measured by colorimetric analysis using chlorostannous phosphomolybdic acid method in the sulphuric acid system (Jackson, 1973).

\section{Statistical analysis}

The data obtained from this experiment were analyzed using two-way ANOVA and conducted by the MSTATC program (version 2.10). The differences between the treatments were analyzed based on Tukey's honestly significant difference test (Tukey's HSD) using the MSTAT-C program. The Simple linear correlation analyses were carried out using SPSS 16.0.

\section{Results}

Characteristics of soils before incubation experiment 
The texture of soils under study is sandy, where the sand content in all soils is higher than $90 \%$. The selected soils widely varied in chemical properties (Table 1). These soils were alkaline, their $\mathrm{pH}$ was 8.33, 8.06, and 8.13 in Arab El-Awamer, West El-Minia, and New Valley, respectively (Table 1). All soils were poorly in organic matter, the content of organic matter is 5.33, 1.65, and $1.16 \mathrm{~g} \mathrm{~kg}^{-1}$ for Arab El-Awamer, West El-Minia, and New Valley, respectively. The content of calcium carbonate in soils is ordered: Arab El-Awamer $\left(326.67 \mathrm{~g} \mathrm{~kg}^{-1}\right)$ i West El-Minia $\left(123.56 \mathrm{~g} \mathrm{~kg}^{-1}\right)$ i New Valley $\left(46.39 \mathrm{~g} \mathrm{~kg}^{-1}\right)$. The concentrations of soluble calcium in the soil extracts were positively correlated with EC, The soluble calcium can be ranked in the order of West El-Minia $\left(61.88 \mathrm{mmol} \mathrm{kg}{ }^{-1}\right)$ i. New Valley $\left(8.50 \mathrm{mmol} \mathrm{kg}{ }^{-1}\right)$ i. Arab El-Awamer $(2.63$ mmol kg-1). The lowest value of soluble calcium was observed in Arab El-Awamer soil, while the highest value was noticed in West El-Minia soil. Generally, the concentrations of soluble cations and anions in the soils under study were noticed in this ranking West El-Minia \& New Valley i, Arab El-Awamer (Table 1).

\section{Soil chemical properties after incubation experiment}

Overall, these soils differed among themselves in $\mathrm{pH}$ values significantly. The soil $\mathrm{pH}$ values significantly decreased with incubation periods increases and New Valley soils, while the soil $\mathrm{pH}$ in Arab El-Awamer decreased non-significant (Table 3). The soil pH in West El-Minia reduced from 8.06 (before incubation) to 7.97 (at day 84) and soil $\mathrm{pH}$ in New Valley declined from 8.13 before incubation to 7.99 at the end of the 84-day incubation. Clearly, there are highly significant differences in the electrical conductivity, soluble cations, and soluble anions between these soils. Compared to the initial soil before the incubation, the soluble calcium in West El-Minia and New Valley soil decreased with increasing incubation periods. While the soluble calcium in Arab El-Awamer soil at (7, 15, and 35 days) decreased and increased at 65 and 84 days compared to the initial soil before the incubation (Table 3 ).

\section{Phosphorus availability}

Bone char applications to the soils resulted in significantly positively the availability of phosphorus affected by the soil type and incubation periods in Arab El-Awamer soil. The application of bone char increased the phosphorus availability in all soils (Table 4). However, the increase in available phosphorus for West El-Minia and New Valley was non-significant compared with the initial soil before the start of the incubation experiment. The application of bone char to Arab El-Awamer soil increased the available phosphorus from 4.47 for unamended soil to 6.96 (represents $55.6 \%$ increase) , 8.11 (represents $81.5 \%$ increase), 7.37 (represents $64.8 \%$ increase), 7.54 (represents $68.8 \%$ increase), and $7.57 \mathrm{mg} \mathrm{kg}^{-1}$ soil (represents $69.4 \%$ increase) after $7,16,35,65$, and 85 days of incubation, respectively. The results revealed the highest concentration of phosphorus availability was observed at the 16 days of the incubation. In West El-Minia soil, The application of bone char increased the available phosphorus from 4.96 for unamended soil 5.54 (represents $11.7 \%$ increase), 4.99 (represents $0.6 \%$ increase), 5.24 (represents $7.5 \%$ increase), and 5.27 $\mathrm{mg} \mathrm{kg}{ }^{-1}$ soil (represents $6.3 \%$ increase) after 16, 35, 65, and 85 days of incubation, respectively. Whilst no significant difference of phosphorus availability after the 7 days of incubation with treated soil by bone char. In the New Valley soil, bone char application to this soil increased the concentrations of phosphorus availability from 4.24 for unamended soil to 4.96 (represents $17.0 \%$ increase) , 4.71 (represents $11.0 \%$ increase), 4.41 (represents $4.1 \%$ increase), 4.61 (represents $8.7 \%$ increase), and $4.73 \mathrm{mg} \mathrm{kg}^{-1}$ soil (represents $11.6 \%$ increase) after $7,16,35,65$, and 85 days of incubation, respectively. The highest concentration of phosphorus availability in New Valley soil was observed at the 7 days of the incubation. The percentage of increase in available phosphorous after adding bone char compared to before incubation was as follows: Arab El-Awamer soil ¿New Valley soil ¿West El-Minia soil (Table 4).

\section{Inorganic phosphorus fractions}

The concentrations of $\mathrm{NH}_{4} \mathrm{Cl}$-Pi fraction varied significantly in all soil types. The application of bone char resulted in significant increases of $\mathrm{NH}_{4} \mathrm{Cl}-\mathrm{Pi}$ fraction in Arab El-Awamer and New Valley soils compared to initial soil before the incubation (unamended soil). While the bone char application caused significant decreases of $\mathrm{NH}_{4} \mathrm{Cl}-\mathrm{Pi}$ fraction in West El-Minia soil compared to initial soil before the incubation (unamended soil). In Arab El-Awamer soil, the bone char addition improved $\mathrm{NH}_{4} \mathrm{Cl}-\mathrm{Pi}$ fraction from $6.10 \mathrm{mg} \mathrm{kg}^{-1}$ soil at 
initial soil before the incubation to $6.120,6.70$, and $6.91 \mathrm{mg} \mathrm{kg}^{-1}$ soil at 35,65 , and 84 days of incubation time, respectively. The amended New Valley soil with bone char enhanced $\mathrm{NH}_{4} \mathrm{Cl}-\mathrm{Pi}$ fraction concentration from $3.530 \mathrm{mg} \mathrm{kg}^{-1}$ soil for initial soil before the incubation (unamended soil) to 4.75, 4.92, 4.81, 4.34, 4.77 $\mathrm{mg} \mathrm{kg}{ }^{-1}$ soil at $7,16,35,65$, and 84 days of incubation time, respectively. Bone char additions to West El-Minia soil caused an increase in the $\mathrm{NH}_{4} \mathrm{Cl}-\mathrm{Pi}$ fraction from $4.59 \mathrm{mg} \mathrm{kg}^{-1}$ soil (unamended soil) to 4.10 , $4.08,3.90,3.89$, and $4.03 \mathrm{mg} \mathrm{kg}^{-1}$ soil at $7,16,35,65$, and 84 days of incubation time, respectively (Table 4).

The content of the $\mathrm{NaHCO}_{3}$-Pi fraction differed significantly in all soils under study. The $\mathrm{NaHCO}_{3}-\mathrm{Pi}$ fraction was significantly affected by the bone char applications in all studied soils compared to the initial soil before the incubation (unamended soil). In Arab El-Awamer soil, the application of bone char increased $\mathrm{NaHCO}_{3}$-Pi fraction from $15.25 \mathrm{mg} \mathrm{kg}-1$ soil at initial soil before the incubation to 28.35, 31.42, 28.26, 28.25, $27.17 \mathrm{mg} \mathrm{kg}-1$ soil at $7,16,35,65$, and 84 days of incubation time, respectively. The results indicated that the highest concentration of $\mathrm{NaHCO}_{3}-\mathrm{Pi}$ fraction was observed at 16 days of incubation and then tended to reduce with the incubation period. In West El-Minia soil, the amended soil with bone char leads to increased $\mathrm{NaHCO}_{3}-\mathrm{Pi}$ fraction from $11.55 \mathrm{mg} \mathrm{kg}-1$ soil at initial soil before the incubation to 25.51, 23.91, 24.91, 25.54, and $24.91 \mathrm{mg} \mathrm{kg-1}$ soil at 7, 16, 35, 65, and 84 days of incubation time, respectively. While the effect of incubation periods on $\mathrm{NaHCO}_{3}$-Pi fraction was non-significant. In New Valley soil, bone char addition increased $\mathrm{NaHCO}_{3}-\mathrm{Pi}$ fraction from $9.12 \mathrm{mg} \mathrm{kg}-1$ soil for the soil without bone char to 26.27, 26.41, $26.69,27.89,25.89 \mathrm{mg} \mathrm{kg}-1$ soil at $7,16,35,65$, and 84 days of incubation time, respectively. While the effect of incubation periods on $\mathrm{NaHCO}_{3}$-Pi fraction was non-significant (Table 4).

The application of bone char to Arab El-Awamer soil caused significant increases in the concentration of $\mathrm{NaOH}-\mathrm{Pi}$ fraction. Applying bone char to Arab El-Awamer soil increased NaOH-Pi fraction from $9.13 \mathrm{mg}$ $\mathrm{kg}^{-1}$ soil (unamended soil) to 9.77, 9.26, 12.10, 9.34, and $9.84 \mathrm{mg} \mathrm{kg}^{-1}$ soil at $7,16,35,65$, and 84 days of incubation time, respectively. The highest content of $\mathrm{NaOH}-\mathrm{Pi}$ fraction was found at day 35 , after which it tended to decline with incubation time. Adding bone char to West El-Minia and New Valley soils had no significant effect on the content of the $\mathrm{NaOH}-\mathrm{Pi}$ fraction (Table 4).

The three soils differ significantly from each other in the HCl-Pi fraction. The application of bone char in all types of soils led to a highly significant increase in HCl-Pi fraction compared to the initial soil before the incubation (unamended soil). The content of the HCl-Pi fraction was higher in Arab El-Awamer soil than in New Valley and West El-Minia soils. Incubation periods did not significantly affect the HCl-Pi fraction in all soils. Application of bone char to Arab El-Awamer soil increased HCl-Pi fraction from $237.4 \mathrm{mg} \mathrm{kg}^{-1} \mathrm{soil}$ for the initial soil before the incubation (unamended soil) to $752.3,745.3,754.0,760.5$, and $754.5 \mathrm{mg} \mathrm{kg}^{-1}$ soil at 7, 16, 35, 65, and 84 days of incubation time, respectively. The HCl-Pi fraction in West El-Minia soil increased with applying bone char from $58.53 \mathrm{mg} \mathrm{kg}^{-1}$ soil for unamended soil before incubation to 584.8 , $583.4,584.8,582.3$, and $580.2 \mathrm{mg} \mathrm{kg}^{-1}$ soil at 7, 16, 35, 65, and 84 days of incubation time, respectively. The addition of bone char to the New Valley soil increased HCl-Pi fraction concentration from $163.1 \mathrm{mg} \mathrm{kg}^{-1}$ soil (unamended soil) to $660.2,666.7,662.6,668.5$, and $663.7 \mathrm{mg} \mathrm{kg}^{-1}$ soil at $7,16,35,65$, and 84 days of incubation time, respectively. The soils under study were characterized by the majority of their $\mathrm{P}$ in the HCl-Pi fraction (Table 4).

The residual-P varied greatly between all soil types. Bone char additions to soils under study increased significantly the residual-P compared to unamended soil. The concentrations of residual-P in Arab ElAwamer soil increased from $33.74 \mathrm{mg} \mathrm{kg}^{-1}$ soil at the initial soil before the incubation (unamended soil) to $73.16,75.16,61.08,62.23$, and $68.21 \mathrm{mg} \mathrm{kg}^{-1}$ soil at 7, 16,35, 65, and 84 days of incubation time, respectively. The concentrations of residual-P in West El-Minia soil increased with bone char applications from $12.15 \mathrm{mg}$ $\mathrm{kg}^{-1}$ soil (initial soil before the incubation or unamended soil) to $39.62,37.59,38.41,37.84$, and $37.07 \mathrm{mg}$ $\mathrm{kg}^{-1}$ soil at $7,16,35,65$, and 84 days of incubation time, respectively. The addition of bone char to the New Valley soil increased residual-P concentrations from $30.95 \mathrm{mg} \mathrm{kg}^{-1}$ soil (unamended soil) to 77.42, 72.77, $75.06,69.68$, and $72.39 \mathrm{mg} \mathrm{kg}^{-1}$ soil at 7, 16, 35, 65, and 84 days of incubation time, respectively (Table 4).

Correlations between Olsen-P and phosphorus fractions with soil properties 
The correlation coefficients between Olsen-P and phosphorus fractions with soil properties are outlined in Table 5. The Olsen-P was positively correlated with soil $\mathrm{pH}\left(\mathrm{r}=0.663^{* *}\right)$. The Olsen-P was negatively correlated with EC $\left(\mathrm{r}=-0.288^{*}\right)$, soluble $\mathrm{Ca}\left(\mathrm{r}=-0.306^{*}\right)$, soluble sulfate $\left(\mathrm{r}=-0.413^{*}\right)$. The concentrations of Olsen-P in all soils under study were positively correlated with $\mathrm{NH}_{4} \mathrm{Cl}-\mathrm{Pi}$ fraction $\left(\mathrm{r}=0.738^{* *}\right), \mathrm{NaHCO}_{3}-\mathrm{Pi}$ fraction $\left(\mathrm{r}=0.520^{* *}\right)$, NaOH-Pi fraction $\left(\mathrm{r}=0.456^{* *}\right)$, HCl-Pi fraction $\left(\mathrm{r}=0.547^{* *}\right)$, and residual-P $\left(\mathrm{r}=0.339^{*}\right)$.

\section{Discussion}

The physical and chemical properties of soils are directly affected by the mineralogy and texture of soils. The concentration of calcium in the soils depends on the $\mathrm{pH}$, CEC, soil type, and mineral composition of the soil (Flis, 2019). Clearly, the soils under study varied in their chemical properties, which in turn play an important role in the release and fractions of phosphorous under applying bone char (Table 3). In our study, the amount of phosphorous released with the addition of bone char was higher in Arab El-Awamer soil than in other soils, this may be attributed to its low content of soluble calcium in soil solution (Figure 1). Factors that affect the availability of phosphorus in the soil are soil mineralogy, soluble and exchangeable calcium, not just soil pH (Penn \& Camberato, 2019). The phosphorus availability improved with amending soils by bone char and increasing incubation time and then tended to decline with incubation time. These results are compatible with a previous study (Morshedizad et al., 2018; Amin, 2021) found that the bone char application to the soil enhanced the phosphorus released with incubation time, then a state of equilibrium occurs between calcium and phosphorus in the soil solution, which leads to a decrease in the phosphorous release as well as the formation of insoluble calcium phosphate compounds. Soluble calcium in soil solution is one of the most important factors that affect phosphorus availability in soils. Increasing the concentrations of soluble calcium and phosphorous in the soil solution leads to the formation of insoluble calcium phosphate compounds, which in turn depends mainly on calcium sources in the soil such as soluble and exchangeable calcium as well as calcium-bearing minerals (Penn \& Camberato, 2019). Furthermore, increased calcium activity and $\mathrm{pH}$ encourage the formation of insoluble calcium phosphate compounds (Pizzeghello et al., 2014). At the same $\mathrm{pH}$, the formation of insoluble calcium phosphate is affected greatly by the calcium to phosphate molar ratios (Mekmene et al., 2009). Therefore, the dissolving of phosphorus from bone char in several soils is greatly affected by the concentrations of $\mathrm{H}^{+}, \mathrm{Ca}^{2+}$, and $\mathrm{H}_{2} \mathrm{PO}_{4}^{-}$in the soil solution (Warren et al., 2009).

The fractions of phosphorus in soils are classified into four categories: labile $\mathrm{P}$ includes $\mathrm{NH}_{4} \mathrm{Cl}-\mathrm{P}$ and $\mathrm{NaHCO}_{3}-\mathrm{Pi}$; moderately labile $\mathrm{P}$ contains $\mathrm{NaOH}-\mathrm{Pi}$; moderately stable $\mathrm{P}$ is $\mathrm{HCl}-\mathrm{Pi}$; and stable $\mathrm{P}$ or nonlabile is residual P (Zhang et al., 2004; Amin, 2018a). Figure 2 shows the effects of soil type and incubation periods on categories of phosphorus fractions under bone char additions. The type and amount of phosphate fertilizers added to the soils greatly affect the phosphorous forms (Pizzeghello et al., 2011). The concentrations of phosphorus fractions in some soils are greatly controlled by moisture content, salinity, particle size distribution, exchangeable cations, and nutrient status in soils (Bai et al., 2020). The concentrations of soluble calcium in soils also played a role in controlling soluble phosphorus (Fig. 2). The $\mathrm{NH}_{4} \mathrm{Cl}-\mathrm{P}$ fraction is expressed as a soluble phosphorous and loosely bound into the exchange sites; this phosphorous is considered available for plant uptake (Zhang \& Kovar, 2000; Manojlovic et al., 2007). The high concentrations of soluble phosphorus in soil solution at high soil $\mathrm{pH}$ values might be attributed to the soluble complexes (ion pairs or complex ions) such as $\mathrm{CaHPO}_{2}{ }^{\mathrm{O}}$ or $\mathrm{CaPO}_{4}$. But mostly, the soluble complexes of phosphorus in soil solution quickly transformed to orthophosphate ions (Pierzynski et al., 2005). The inorganic phosphorous faction $\left(\mathrm{NaHCO}_{3}-\mathrm{Pi}\right)$ is adsorbed on the soil surfaces, labile, and available for plants (Tian et al., 2019). The $\mathrm{NaHCO}_{3}$-Pi fraction was positively correlated with added $\mathrm{P}$ (He et al., 2006). NaOH-Pi represents inorganic phosphorous faction associated strongly by chemisorption into surfaces of $\mathrm{Al}$ and $\mathrm{Fe}$ oxides (Costa et al., 2016). Some studies found that the addition of phosphate fertilizers did not significantly affect the inorganic phosphorus extracted by NaOH (NaOH-Pi) (He et al., 2006; Amin \& Mihoub, 2021). The HCl-Pi represents inorganic $\mathrm{P}$ associated with $\mathrm{Ca}$ was founded in apatite or octacalcium phosphate (Costa et al., 2016). The relative distribution of phosphorus fractions followed the order of $\mathrm{HCl}-\mathrm{P} i$ Residual $\mathrm{P} i \mathrm{NaHCO}_{3}-\mathrm{P} i \mathrm{NaOH}-$ $\mathrm{P} i \mathrm{NH}_{4} \mathrm{Cl}-\mathrm{P}$. The highest concentrations of $\mathrm{P}$ fractions are the insoluble $\mathrm{P}$ associated with calcium under bone char applications in soils (Zimmer et al., 2018; Amin \& Mihoub, 2021). The available phosphorus was 
positively correlated with HCl-P fraction (Kolahchi \& Jalali, 2012). At high $\mathrm{pH}$ and calcium activity leads to increase the formation of insoluble calcium phosphate (Pizzeghello et al., 2014). Generally, numerous studies found that the higher $\mathrm{pH}$ and calcium content in the soils can interpret the higher concentration of HCl-P which expresses of $\mathrm{P}$ associated with calcium (Weyers et al., 2016; Amin, 2018b). The residual P fraction includes the forms of phosphorous that are chemically stable and recalcitrant (Costa et al., 2016). The application of phosphate fertilizer to calcareous sandy loam soil led to significant increased the residualP fraction compared to unfertilized soil (Ahmad et al., 2018). Amin and Mihoub (2021) found that the application of bone char to calcareous sandy soil resulted in a significant increase in the content of residual-P fraction compared to unamended soil.

\section{Conclusions}

This study provides a future vision very promising for the use of bone char as a clean, cheap, and renewable alternative to phosphate chemical fertilizers. Therefore, the chemical properties of alkaline sandy soils are considered important factors that control the bone char effect on the availability and distribution of phosphorus. The amount of phosphorous dissolved from bone char increased in soil with low calcium content and electrical conductivity. Overall results show that the soluble calcium was a significant factor in $\mathrm{P}$ availability with incubation periods. Most phosphorus fractions increased with applying bone char. We can conclude that the bone char amendment affected the availability and distribution of phosphorus in alkaline agricultural sandy soils. Nowadays, the use of bone char can be increased due to its availability and lower cost compared to chemical phosphate fertilizers.

\section{Data Availability Statement}

The data that support the findings of this study are available from the corresponding author upon reasonable request.

\section{Conflict of Interest}

We wish to draw the attention of the Editor to the following facts, which may be considered as potential conflicts of interest and to significant financial contributions to this work: The nature of the potential conflict of interest is described below: No conflict of interest exists. The authors declare that they have no known competing financial interests or personal relationships that could have appeared to influence the work reported in this paper. We wish to confirm that there are no known conflicts of interest associated with this publication and there has been no significant financial support for this work that could have influenced its outcome.

\section{An author contribution statement}

1- I developed the original idea and the protocol, abstracted and analyzed data, wrote the manuscript, is the guarantor, contributed to the development of the protocol and prepared the manuscript.

2- I agreed to be accountable for all aspects of the work in ensuring that questions related to the accuracy or integrity of any part of the work are appropriately investigated and resolved.

3- I give final approval of the version to be published. Each author should have participated sufficiently in the work to take public responsibility for appropriate portions of the content.

\section{References}

Ahmad, M., Ahmad, M., El-Naggar, A. H., Usman, A. R. A., Abduljabbar, A., Vithanage, M., Elfaki, J., Al-Faraj, A. \& Al-Wabel, M. I. (2018). Aging effects of organic and inorganic fertilizers on phosphorus fractionation in a calcareous sandy loam soil. Pedosphere , 28, 873-883.

Amin, A. A. (2018a). Phosphorus dynamics and corn growth under applications of corn stalks biochar in a clay soil. Arabian Journal of Geosciences, 11, 379. 
Amin, A. A. (2018b). Availability and transformations of phosphorus in calcareous sandy soil as affected by farmyard manure and elemental sulfur applications. Alexandria Science Exchange Journal , 39, 98-111.

Amin, A. A. (2020). Sulfur, Na2-EDTA and their mixture effects on phosphorus release from cow bone char in P-poor sandy soil.Environmental Technology \& Innovation, 17, 100636.

Amin, A. A. (2021). Enhancement of releasing phosphorus from bone char in calcareous sandy soil under applying different levels of water salinity. Journal of Soil Science and Plant Nutrition, 21, 476-486.

Attallah, M. F., Metwally, S. S., Moussa, S. I. \& Soliman, M. A. (2019). Environmental impact assessment of phosphate fertilizers and phosphogypsum waste: Elemental and radiological effects.Microchemical Journal, $146,789-797$.

Bai, J., Ye, X., Jia, J., Zhang, G., Zhao, Q., Cui, B. \& Liu, X. (2017). Phosphorus sorption-desorption and effects of temperature, $\mathrm{pH}$ and salinity on phosphorus sorption in marsh soils from coastal wetlands with different flooding conditions. Chemosphere, 188, 677-688.

Bai, J., Yu, L., Ye, X., Yu, Z., Wang D., Guan, Y., Cui, B. \& Liu, X. (2020). Dynamics of phosphorus fractions in surface soils of different flooding wetlands before and after flow-sediment regulation in the Yellow River Estuary, China. Journal of Hydrology, 580, 124256.

Baruah, T. C. \& Barthakur, H. P. (1997). A Textbook of Soil Analysis . India, New Delhi: Vikas Publishing House PVT LTD.

Boskey, A. L. (2007). Mineralization of bones and teeth.Elements, 3, 385-391.

Chen, C. R., Condron, L. M., Davis, M. R. \& Sherlock, R. R. (2000). Effects of afforestation on phosphorus dynamics and biological properties in a New Zealand grassland soil. Plant and Soil, 220, 151-163.

Cordell, D., Drangert, J. F. \& White, S. (2009). The story of phosphorus: global food security and food for thought. Global Environmental Change, 19, 292-305.

Costa, M. G., Gama-Rodrigues, A. C., Gonçalves, J. L. M., Gama-Rodrigues, E. F., Sales, M. V. S. \& Aleixo, S. (2016). Labile and non-labile fractions of phosphorus and its transformations in soil underEucalyptus plantations, Brazil. Forests, 7, 15.

Flis, S. (2019). Calcium: Improved plant health and nutrition.Crops \&3 Soils magazine, 28-30.

Glæsner, N., Hansen, H. C. B., Hu, Y., Bekiaris, G. \& Bruun, S. (2019). Low crystalline apatite in bone char produced at low temperature ameliorates phosphorus-deficient soils. Chemosphere, 223, 723-730.

He, Z., Griffin, T. S. \& Honeycutt, C. W. (2006). Soil phosphorus dynamics in response to dairy manure and fertilizer applications. Soil Science, 171, 598-609.

Hedley, M. J., Stewart, J. W. B. \& Chauhan, B.S. (1982). Changes in inorganic and organic soil phosphorus fractions induced by cultivation practices and by laboratory incubations. Soil Science Society of America Journal, 46, 970-976.

Hinsinger, P. (2001). Bioavailability of soil inorganic P in the rhizosphere as affected by root-induced chemical changes: a review.Plant and Soil, 237, 173-195.

Hopkins, B. G. \& Ellsworth, J. W. (2005). Phosphorus availability with alkaline/ calcareous soil. Western Nutrient Management Conference. Salt Lake City, UT, USA, 6, 88-93.

Jackson, M. L. (1973). Soil Chemical Analysis . New Delhi: Prentice-Hall, Inc., Englewood Cliffs. N.J.

Jalali, M. \& Jalali, M. (2016). Relation between various soil phosphorus extraction methods and sorption parameters in calcareous soils with different texture. Science of the Total Environment , 566-567, 1080-1093. 
Khan, M. N., Mobin, M., Abbas, Z. K. \& Alamri, S. A. (2018). Fertilizers and their contaminants in soils, surface and groundwater. In: D. A. DellaSala \& M. I. Goldstein (Eds.), The encyclopedia of the Anthropocene (pp. 225-240). Oxford: Elsevier.

Kolahchi, Z. \& Jalali, M. (2012). Speciation of phosphorus in phosphorus-amended and leached calcareous soils using chemical fractionation. Polish Journal of Environmental Studies, 21, 395-400.

Leytem, A. B. \& Mikkelsen, R. L. (2005). The nature of phosphorus in calcareous soils. Better Crops, 89, 11-13.

Li, F., Liu, L., Liu, J. \& Yang, K. (2019). Abiotic and biotic controls on dynamics of labile phosphorus fractions in calcareous soils under agricultural cultivation. Science of the Total Environment, 681, 163-174.

Manojlovic, D., Todorovica, M., Jovicic, J., Krsmanovic, V. D., Pfendt, P. A. \& Golubovic, R. (2007). Preservation of water quality in accumulation Lake Rovni: the estimate of the emission of phosphorus from inundation area. Desalination, 213, 104-109.

Mekmene, O., Quillard, S., Rouillon, T., Bouler, J., Piot, M. \& Gaucheron, F. (2009). Effects of pH and $\mathrm{Ca} / \mathrm{P}$ molar ratio on the quantity and crystalline structure of calcium phosphates obtained from aqueous solutions. Dairy Science \& Technology, 89, 301-316.

Morshedizad, M., Panten, K., Klysubun, W. \& Leinweber, P. (2018). Bone char effects on soil: sequential fractionations and XANES spectroscopy.Soil, 4, 23-35.

Olsen, S. R., Cole, C. V., Watanabe, F. S. \& Dean, L. A. (1954). Estimation of available phosphorus in soils by extraction with sodium bicarbonate. Circular/United States Department of Agriculture (no. 939).

Penn, C. J. \& Camberato, J. J. (2019). A critical review on soil chemical processes that control how soil pH affects phosphorus availability to plants. Agriculture, 9, 120.

Pierzynski, G. M., McDowell, R. W. \& Sims, J. T. (2005). Chemistry, cycling, and potential movement of inorganic phosphorus in soils. In: J. Sims \& A. Sharpley (Eds.), Phosphorus: Agriculture and the environment (pp. 53-86). Madison: ASA, CSSA, SSSA.

Pizzeghello, D., Berti, A., Nardi, S. \& Morari, F. (2011). Phosphorus forms and P sorption in three alkaline soils after long-term mineral and manure applications. Agriculture, Ecosystems and Environment,141, 58-66.

Pizzeghello, D., Berti, A., Nardi, S. \& Morari, F. (2014). Phosphorus-related properties in the profiles of three Italian soils after long-term mineral and manure applications. Agriculture, Ecosystems and Environment, 189, 216-228.

Sarkar, D., Kar, S. K., Chattopadhyay, A., Shikha, R. A., Tripathi, V. K., Dubey, P. K. \& Abhilash, P. C. (2020). Low input sustainable agriculture: a viable climate-smart option for boosting food production in a warming world. Ecological Indicators, 115, 106412.

Siebers, N. \& Leinweber, P. (2013). Bone char-a clean and renewable fertilizer with cadmium immobilizing capability. Journal of Environmental Quality, 42, 405-411.

Tian, H., Cheng, X., Han, H., Jing, H., Liu, X. \& Li, Z. (2019). Seasonal variations and thinning effects on soil phosphorus fractions inLarix principis-rupprechtii Mayr. plantations. Forests,10, 172.

Warren, G. P., Robinson, J. S. \& Someus, E. (2009). Dissolution of phosphorus from animal bone char in 12 soils.Nutrient Cycling in Agroecosystems, 84, 167- 178.

Wopenka, B. \& Pasteris, J. D. (2005). A mineralogical perspective on the apatite in bone. Materials Science and Engineering: $C, 25,131-143$.

Zhang, H. \& Kovar, J. L. (2000). Phosphorus fractionation. In: G. M. Pierzynski (Ed.), Methods of phosphorus analysis for soils, Sediments, Residuals, and Waters (pp. 50-59), Southern Cooperative Series, Bulletin No 396. 
Zhang, T. Q., MacKenzie, A. F., Liang, B. C. \& Drury, C. F. (2004). Soil test phosphorus and phosphorus fractions with long-term phosphorus addition and depletion. Soil Science Society of America Journal,68, $519-528$.

Zhu, J., Li, M. \& Whelan, M. (2018). Phosphorus activators contribute to legacy phosphorus availability in agricultural soils: a review.Science of the Total Environment , 612, 522-537.

Zimmer, D., Kruse, J., Siebers, N., Panten, K., Oelschläger, C., Warkentin, M., Hu, Y., Zuin, L. \& Leinweber, P. (2018). Bone char vs. S-enriched bone char: multi-method characterization of bone chars and their transformation in soil. Science of the Total Environment, 643, 145-156.

Zimmer, D., Panten, K., Frank, M., Springer, A. \& Leinweber, P. (2019). Sulfur-enriched bone char as alternative P fertilizer: spectroscopic, wet chemical, and yield response evaluation. Agriculture, 9, 1-22.

\section{Hosted file}

Table_1.docx available at https://authorea.com/users/441525/articles/542008-release-anddistribution-changes-of-phosphorus-in-three-alkaline-sandy-soils-as-a-function-of-bonechar-applications

\section{Hosted file}

Table_2.docx available at https://authorea.com/users/441525/articles/542008-release-anddistribution-changes-of-phosphorus-in-three-alkaline-sandy-soils-as-a-function-of-bonechar-applications

\section{Hosted file}

Table_3.docx available at https://authorea.com/users/441525/articles/542008-release-anddistribution-changes-of-phosphorus-in-three-alkaline-sandy-soils-as-a-function-of-bonechar-applications

\section{Hosted file}

Table_4.docx available at https://authorea.com/users/441525/articles/542008-release-anddistribution-changes-of-phosphorus-in-three-alkaline-sandy-soils-as-a-function-of-bonechar-applications

\section{Hosted file}

Table_5.docx available at https://authorea.com/users/441525/articles/542008-release-anddistribution-changes-of-phosphorus-in-three-alkaline-sandy-soils-as-a-function-of-bonechar-applications

\section{Hosted file}

Figure_1.docx available at https://authorea.com/users/441525/articles/542008-release-anddistribution-changes-of-phosphorus-in-three-alkaline-sandy-soils-as-a-function-of-bonechar-applications

\section{Hosted file}

Figure_2.docx available at https://authorea.com/users/441525/articles/542008-release-anddistribution-changes-of-phosphorus-in-three-alkaline-sandy-soils-as-a-function-of-bonechar-applications 